\title{
Voltammetry for Onsite Simultaneous Metal Analysis
}

\section{ISSN : 2688-8394}

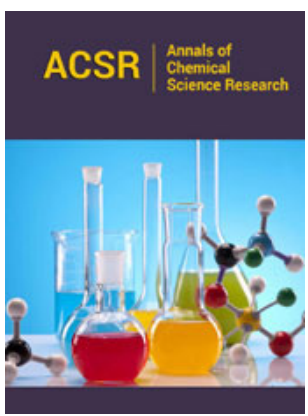

*Corresponding author: Pipat Chooto, Department of Chemistry, Faculty of Science, Prince of Songkla University, Thailand

Submission: 望孟 June 06, 2019

Published: 䘧June 10, 2019

Volume 1 - Issue 3

How to cite this article: Chooto $\mathrm{P}$, Voltammetry for Onsite Simultaneous Metal Analysis. Ann Chem Sci Res. 1(3). ACSR.000514.2019.

DOI: 10.31031/ACSR.2019.01.000514

Copyright@ Pipat Chooto, This article is distributed under the terms of the Creative Commons Attribution 4.0 International License, which permits unrestricted use and redistribution provided that the original author and source are credited.

\author{
Pipat Chooto* \\ Department of Chemistry, Faculty of Science, Prince of Songkla University, Thailand
}

\begin{abstract}
With the objective of analyzing metal ions simultaneously in several samples which can be applied in various areas, electrochemical methods based on anodic stripping voltammetry are prominent due to the fact that their analytical performance can be increased by electrode modifications. The development of electrodes and methods together with the availability of small and low cost instrument would be beneficial for onsite analysis and makes it much more practical.
\end{abstract}

Keywords: Voltammetry; Electrochemical methods; Onsite analysis; Metal ion determination ; Simultaneous analysis

Heavy metals (HMs) have caused several problems for all living things on earth so far [1]. They do have both beneficial and harmful effects. Some of them in specific concentrations, oxidation numbers and forms are essential to the body of living things whereas others can be deleterious. HMs have been well known for a long time to play important roles in a number of samples especially environment and food. The greater role they have in everyday life, the greater the need for monitoring their concentrations. Several techniques have been developed to gain better figure of merits and advantages. And it would be rewarding if those techniques are able to analyze HMs simultaneously and onsite, especially for environmental analysis.

Normally in standard metal ion analysis, the techniques require costly and sophisticated instruments, not to mention sample preparation. However, the main advantages of these techniques include limit of detection and analytical performance [2]. In the case that these characteristics are not the top priority compared to capability of simultaneous analysis, then electrochemical methods become very attractive and outstanding.

The most useful electrochemical method for metal analysis is anodic stripping voltammetry (ASV) [3], followed by probably amperometry, cyclic voltammetry, electrochemical impedance spectroscopy (EIS) and potentiometry. ASV consists of three steps namely deposition, equilibration and stripping. With pulsing of the potential namely, square wave (SW) and differential pulse (DP), the sensitivity can be increased significantly due to the increase of Faradaic current. However, the selection of pulsing is still a matter of experimentation. In other words, there are no such ways to determine that the pulsing should be SW and DP. This is because it depends on the nature of systems under investigation a lot. It must be stated here that the prominent and unique feature of ASV is the way that the stripping peak of each metal appears at different potentials, not to mention the way that these potentials very much depend on specific conditions to make method selectivity successfully controllable. Additionally, another specific aspect that currently helps increase the sensitivity and well as specificity is the modification of the electrode.

There are a number of ways to modify the electrode, mainly by increasing the surface areas by using a number of porous nanomaterials such as graphene, nanometals or nanosilica [4]. Of course, it has to be mentioned here that the first thing to think about here is the substrate electrodes which glassy carbon seems to be the most common but not necessary to be the best and the opportunities are overwhelming, so more investigations are encouraged here. Next is the use of another specific metal to support the deposition which is very useful in ASV analysis. Bismuth (Bi) is the most common to use instead of mercury (Hg) with the main advantage of no oxygen interference and low toxicity [5]. However, other metals should also help in 
specific applications as well, such as tin(Sn) and antimony(Sb) among others, of which further investigations in details are also still of challenge. The next strategy is to use special compounds to help attract metal ion via for example complexation and at the same time the compounds can provide selectivity. However, with the focus on simultaneous analysis, the compound should be able to facilitate as many metals as possible. Also, as in conventional ways, the use of masking agents and specific compound for each metal to improve individual analyte might also be applied. And when talking about onsite analysis, in situ preparation and small scaled equipment such as the use of screen-printed electrode (SPE) [6] need to be highlighted. In the case of voltammetry, at present small and not expensive instruments are commercially available and used increasingly to serve this purpose [7].

Currently, there are many current research articles in this area of metal determination by ASV [8]. In our case, we have shown that
$\mathrm{Bi} /$ chitosan/mesoporous silica can be used in the determination of $\mathrm{Cd}$ (II) and $\mathrm{Pb}$ (II) in water lily in polluted water resources [9]. Our work might also prove that certain compounds can be used in-situ for simultaneous ASV analysis of various metals in addition to $\mathrm{Cd}$ (II) and $\mathrm{Pb}$ (II) [10]. However, the fact that Boron doped diamond (BDD) works well with $\mathrm{Pb}$ (II) [11] might turn out that BDD alone can be applied here for simultaneous analysis which would make it easier for onsite applications. BDD has so many advantages and the price is not that high when considering the ruggedness and less noise. Furthermore, the compounds that were used in other techniques and have been used before but with less satisfactory results should be further experimented and developed as well for simultaneous electrochemical applications [12]. Typical involving applications along with the analytical performance have been summarized in Table 1 as well as references for further research development.

Table 1: Typical recent simultaneous analysis focusing on more than two metals and onsite applications by electrochemical methods.

\begin{tabular}{|c|c|c|c|c|c|c|c|c|}
\hline Entry & Metals & Electrode & Dep. Pot/Time & $\begin{array}{l}\text { Solution Condi- } \\
\text { tions }\end{array}$ & Pulsing & Lowest LOD & Sample & Ref \\
\hline 1 & $\begin{array}{l}\mathrm{Pb}(\mathrm{II}), \\
\mathrm{As}(\mathrm{III}) \\
\mathrm{Hg}(\mathrm{II})\end{array}$ & Gold-sputtered plastic electrode & $-0.6 \mathrm{~V} / 240 \mathrm{~s}$ & $\begin{array}{c}0.8 \mathrm{M} \mathrm{HNO}_{3}-0.1 \mathrm{M} \\
\mathrm{KCl}\end{array}$ & DPASV & $\begin{array}{l}0.5 \mathrm{mg} / \mathrm{L} \\
\mathrm{Hg}(\mathrm{II})\end{array}$ & cosmetics & 13 \\
\hline 2 & $\begin{array}{l}\mathrm{Cd}(\mathrm{II}) \\
\mathrm{Pb}(\mathrm{II}) \\
\mathrm{Cu}(\mathrm{II}) \\
\mathrm{Hg}(\mathrm{II})\end{array}$ & $\begin{array}{c}\mathrm{Fe}_{3} \mathrm{O}_{4} \text { nanoparticles/ fluorinated } \\
\text { multi-walled carbon nanotubes } \\
\left(\mathrm{Fe}_{3} \mathrm{O}_{4} / \mathrm{F}-\mathrm{MWCNTs}\right)\end{array}$ & $-1.2 \mathrm{~V} / 180 \mathrm{~s}$ & $\begin{array}{l}0.1 \mathrm{M} \text { acetate } \\
\text { buffer solution } \\
(\mathrm{NaAc}-\mathrm{HAc} \\
\text { pH=5.0) }\end{array}$ & SWASV & $\begin{array}{l}0.02 \mathrm{nM} \\
\mathrm{Pb}(\mathrm{II})\end{array}$ & $\begin{array}{l}\text { River water/ } \\
\text { soyabean }\end{array}$ & 14 \\
\hline 3 & $\begin{array}{l}\mathrm{Cd}(\mathrm{II}) \\
\mathrm{Pb}(\mathrm{II}) \\
\mathrm{Cu}(\mathrm{II}) \\
\mathrm{Hg}(\mathrm{II})\end{array}$ & $\begin{array}{c}\text { Polypyrrole-Reduced Graphene } \\
\text { Oxide (PPy-rGO) Nanocomposite } \\
\text { Hydrogels }\end{array}$ & $-1.0 \mathrm{~V} / 720 \mathrm{~s}$ & $\begin{array}{c}0.1 \mathrm{M} \mathrm{HCl} \text { and } \\
0.3 \mathrm{M} \mathrm{KCl}\end{array}$ & SWASV & $\begin{array}{l}0.3 \mathrm{nM} \\
\mathrm{Pb}(\mathrm{II})\end{array}$ & Lake water & 15 \\
\hline 4 & $\begin{array}{l}\mathrm{Cd}(\mathrm{II}) \\
\mathrm{Pb}(\mathrm{II}) \\
\mathrm{Cu}(\mathrm{II})\end{array}$ & $\begin{array}{l}\text { A rotating disk of glassy carbon elec- } \\
\text { trode modified with thin mercury } \\
\text { film (RDGCE/TMF) }\end{array}$ & $-1.2 \mathrm{~V} / 300 \mathrm{~s}$ & $0.1 \mathrm{M} \mathrm{HCl}$ & SWASV & $\begin{array}{l}\text { approx. } 30 \\
\text { ppb for all } \\
\text { HMs }\end{array}$ & $\begin{array}{l}\text { Leaves and } \\
\text { soil }\end{array}$ & 16 \\
\hline 5 & $\begin{array}{l}\mathrm{Pb}(\mathrm{II}) \\
\mathrm{Cd}(\mathrm{II})\end{array}$ & $\begin{array}{l}\text { Disposable polyethylene dioxyth- } \\
\text { iophene and polystyrene sulfonate } \\
\text { carbon cloth working electrode } \\
\text { (PPCCE) }\end{array}$ & $-1.0 \mathrm{~V} / 160 \mathrm{~s}$ & $\begin{array}{l}\mathrm{NaAc}-\mathrm{HAc}, \\
\mathrm{pH}=3.5\end{array}$ & DPASV & $\begin{array}{c}0.005 \mu \mathrm{M} \\
\left(1.90 \mathrm{mgL}^{-1}\right) \\
\mathrm{Pb}(\mathrm{II})\end{array}$ & River water & 17 \\
\hline 6 & $\begin{array}{l}\mathrm{Zn}(\mathrm{II}) \\
\mathrm{Cd}(\mathrm{II}) \\
\mathrm{Pb}(\mathrm{II}) \\
\mathrm{Cu}(\mathrm{II})\end{array}$ & BiE on GCE & $-1.4 \mathrm{~V} / 120 \mathrm{~s}$ & $\begin{array}{c}\mathrm{NaAc}-\mathrm{HAc}, \\
\mathrm{pH}=4.5\end{array}$ & DPASV & $\begin{array}{l}\text { 0.65ppb } \\
\mathrm{Pb}(\mathrm{II})\end{array}$ & River water & 5 \\
\hline 7 & $\begin{array}{l}\mathrm{As}(\mathrm{III}), \\
\mathrm{Pb}(\mathrm{II}), \\
\mathrm{Hg}(\mathrm{II})\end{array}$ & Gold nanostar electrode & $-0.6 \mathrm{~V} / 180 \mathrm{~s}$ & $0.1 \mathrm{M} \mathrm{HCl}$ & SWASV & $\begin{array}{l}0.8 p p b \\
\text { As(III) }\end{array}$ & $\begin{array}{l}\text { Ground } \\
\text { water }\end{array}$ & 18 \\
\hline
\end{tabular}

All of the above have laid the background for the development of methods for onsite simultaneous analysis of metals. Electrochemical methods seem to work best for this objective and ASV is the method of choice. With refined modifications and miniaturized instruments, the purposes can be further achieved and can be applied well in practice for the analysis of real samples. Newly developed techniques hopefully can be used onsite conveniently in the near future, at least for environmental samples. 
With typical references for each subtopic, this article is intended to initiate more and greater experimentation which of course there are a lot more to search for, not just to help solve currently encountered problems, here in particular from the presence and absence of a number of metals, but should prevent the forthcoming situations that might be harmful to living things and involving ecosystem. Also, it would be great to have a lot more creative scientific treasures and innovations in the new world but with careful consideration of the effects and impact that those new things may have to lead to scientific assets that are purely green, but not so fast or not that fast to be frightened short time or long time later, and are based on detailed investigations in all dimension, to be delivered as well as to educate all individuals of concern. And, with the narrow context of metal analysis, of course the new innovations for onsite simultaneous determination would be expected to be one of the sciences which are of great help to the future world.

\section{References}

1. Chen SH, Li YX, Li PH, Xiao XY, Jiang M, et al. (2018) Electrochemical spectral methods for trace detection of heavy metals: A review. TrAC Trends in Analytical Chemistry 106: 139-150.

2. Feist B, Sitko R (2019) Fast and sensitive determination of heavy metal ions as batophenanthroline chelates in food and water samples after dispersive micro-solid phase extraction using graphene oxide as sorbent. Microchemical Journal 147: 30-36.

3. Skiba TV, Gou H (2019) Anodic stripping voltammetry for direct determination of heavy metals in bovine seminal plasma using thick film modified graphite electrodes. Microchemical Journal 147: 818-823.

4. Chooto P (2017) Modified electrodes for determining trace metal ions. In: Stoytcheva M, Zlatev R (Eds.), Applications of the voltammetry, Publisher: In Tech, Rijeka, Croatia, Balkans, USA, pp. 129-152.

5. Thanh NM, Hop NV, Luyen ND, Phong NH, Toan TTT (2019) Simultaneous determination of $\mathrm{Zn}(\mathrm{II}), \mathrm{Cd}(\mathrm{II}), \mathrm{Pb}(\mathrm{II})$, and $\mathrm{Cd}(\mathrm{II})$ using differential pulse anodic stripping voltammetry at a bismuth film-modified electrode. Advances in Materials Science and Engineering 2019:1-11.

6. Frutos-Puerto S, Miró C, Pinilla-Gil E (2019) Nafion-protected sputtered-bismuth screen-printed electrode for on-site voltammetric measurements of $\mathrm{Cd}(\mathrm{II})$ and $\mathrm{Pb}(\mathrm{II})$ in Natural Water Samples. Sensors 19(2): 279.

7. Holmes J, Pathirathna P, Hashemi P (2019) Novel frontiers in voltammetric trace metal analysis: Towards real time, on-site, in situ measurements. TrAC Trends in Analytical Chemistry 111: 206-219.
8. Tyszczuk-Rotko K (2019) Metal film electrodes prepared with a reversibly deposited mediator in voltammetric analysis of metal ions. Current Opinion in Electrochemistry.

9. Chooto P, Somkid M (2019) Determination of lead(II) and cadmium(II) in water lily stems using a bismuth film electrode. Journal of Electrochemical Science and Engineering 9: 153-164.

10. Phlay S, Tapachai WA, Duangthong S, Worattananurak P, Chooto P (2019) Simultaneous determination of trace levels of Cd(II) and $\mathrm{Pb}(\mathrm{II})$ in tap water samples by anodic stripping voltammetry with 2-mercaptobenzothiazole modified electrode. Journal of Electrochemical Science and Engineering 10: 11-20.

11. Chooto P, Wararatananuruk P, Innuphat C (2010) Determination of trace levels of $\mathrm{Pb}(\mathrm{II})$ in tap water by anodic stripping voltammetry with boron-doped diamond electrode. ScienceAsia 36: 150-156.

12. Kheirandish S, Ghaedi M, Dashtian K, Jannesar R, Montazerozohori M, et al. (2017) Simultaneous removal of Cd(II), Ni(II), Pb(II) and Cu(II) ions via their complexation with HBANSA based on a combined ultrasoundassisted and cloud point adsorption method using CSG-BiPO ${ }_{4} / \mathrm{FePO}_{4}$ as novel adsorbent: FAAS detection and optimization process. J Colloid Interface Sci 500: 241-252.

13. Wang W, Bao N, Yuan W, Si N, Bai H, et al. (2019) Simultaneous determination of lead, arsenic, and mercury in cosmetics using a plastic based disposable electrochemical sensor. Microchemical Journal 148: 240-247.

14. Wu W, Jia M, Zhang Z, Chen X, Zhang Q, et al. (2019) Sensitive, selective and simultaneous electrochemical detection of multiple heavy metals in environment and food using a low cost $\mathrm{Fe}_{3} \mathrm{O}_{4}$ nanoparticles/fluorinated multi-walled carbon nanotubes sensor. Ecotoxicol Environ Saf 175: 243 250 .

15. Suvina V, Murali Krishna S, Nagaraju DH, Melo JS, Geetha Balakrishna R (2018) Polypyrrole-Reduced Graphene Oxide Nanocomposite Hydrogels: A Promising electrode material for the simultaneous detection of multiple heavy metal ions. Materials Letters 232: 209-212.

16. Khdaychi Y, Idrissi L, Souabi S, Kadmi Y (2018) Simultaneous electrochemical analysis of heavy metals in atmospheric deposits. J Mater Environ Sci 9(7): 2189-2200.

17. Shi H, Zhu F, Zhou X, Li H, Yang F, et al. (2019) Large scale fabrication of disposable carbon cloth electrochemical sensors for simultaneous determination of heavy metal ion. Journal of Electroanalytical Chemistry 840: 328-337.

18. Dutta S, Strack G, Kurup P (2019) Gold nanostar electrodes for heavy metal detection. Sensors and Actuators B: Chemical 281: 383-391. 